\title{
Zircon age constraints on the provenance of Llandovery to Wenlock sandstones from the Midland Valley terrane of the Scottish \\ Caledonides
}

\author{
E.R. Phillips ${ }^{1 *}$, R.A. Smith ${ }^{1}$, P. Stone ${ }^{1}$, M. Horstwood ${ }^{2} \&$ V. Pashley ${ }^{2}$ \\ ${ }^{1}$ British Geological Survey, Murchison House, West Mains Road, Edinburgh EH9 3LA, UK \\ ${ }^{2}$ Natural Environmental Research Council Isotope Geoscience Laboratories, Keyworth, Nottingham \\ NG12 5GG, UK \\ * corresponding author e-mail: erp@bgs.ac.uk
}

\section{Synopsis}

Detrital zircon populations within the Llandovery to Wenlock sandstones of the southern Midland Valley of Scotland indicate that the recycled orogenic provenance for these sedimentary rocks was essentially bimodal, comprising a younger Lower Palaeozoic component and an older predominantly Mesoproterozoic component. The Lower Palaeozoic contribution is dominated by Arenig/Llanvirn (c. $475 \mathrm{Ma}$ ) zircons interpreted as having been derived from a volcanic-plutonic source located within the Midland Valley terrane. The dominant Mesoproterozoic component within the sandstones is c. $1000 \mathrm{Ma}$ and is thought to represent detritus shed from a Grenvillian ( 1000-1800Ma) basement to the Midland Valley terrane. The scarcity of Archaean zircons precludes the Grampian metamorphic terrane Dalradian Supergroup as a supplier of sediment to the Ordovician-Silurian basins located along the southern margin of the Midland Valley. The age profiles of detrital zircon populations do not fit with a simple model of unroofing of a volcanic-arc complex. Rather they point to the periodic uplift of fault-bound, dismembered blocks of volcanic and plutonic rocks during a prolonged (Llandovery through to at least early Devonian) period of sinistral strike-slip deformation, and it was this which controlled basin development, sedimentary facies distribution and deformation along the southern side of the Midland Valley terrane. 


\section{Introduction}

The Midland Valley terrane of central Scotland separates the Neoproterozoic metamorphic rocks of the Grampian Highlands from the Lower Palaeozoic accretionary complex of the Southern Uplands (Fig. 1). The terrane is bounded to the north by the Highland Boundary Fault Zone and to the south by the Southern Upland Fault. The role of the Midland Valley in the history of Caledonian terrane accretion has long been the source of interest and speculation. Lambert \& McKerrow (1976), Leggett (1980) and Leggett et al. (1982), amongst others, regarded the Lower Palaeozoic sedimentary rocks of the Midland Valley terrane as having been deposited in a fore-arc basin that divided the accretionary complex of the Southern Uplands terrane, from a basement-arc terrane to the north. In another interpretation, sediment derived from uplift of the Grampian terrane was dispersed across the Midland Valley and accumulated within the postulated Southern Uplands trench (Hutchison \& Oliver 1998; Oliver et al. 2000). Alternatively, for most of the Ordovician to earliest Devonian interval, the Midland Valley terrane may have formed an arc-inter arc region which supplied sediment into a fore-arc basin located immediately to the south (Bluck, et al. 1980; Bluck 1983, 1984; Smith et al. 2001; Bluck et al. 2006).

The structural geometry of the Southern Uplands terrane is consistent with it having developed as an accretionary thrust complex at the Laurentian continental margin during northward subduction of the Iapetus Ocean. The evolution of this terrane has been interpreted in terms of a fore-arc, supra-subduction zone prism (McKerrow et al. 1977; Leggett et al. 1979; Leggett et al. 1982; Leggett 1987; Needham 2004), although the northern (Ordovician) part has also been interpreted as a subsiding, fore-arc shelf sequence rather than trench deposits (Armstrong et al. 1996; Armstrong \& Owen 2001). In an alternative model, the terrane is envisaged as having developed from an Ordovician back-arc setting into a mid-Silurian foreland basin that migrated onto the Avalonian continent following closure of the Iapetus Ocean (Morris 1987; Stone et al. 1987; Kneller 1991; Kneller et al. 1993). A recent evaluation of the basin thermal history in the Southern Uplands terrane has ruled out the back-arc component of this model (Stone \& Merriman 2004), but the later evolution into a foreland fold and thrust belt remains likely, as does some link with the wholly Avalonian development of the coeval Windermere Supergroup foreland basin in the southern Lake District. 
Until recently the presence of fresh, southerly derived andesitic detritus within some of the turbiditic sandstones of the Southern Uplands (most notably the Caradocian Portpatrick and Galdenoch formations) had been assumed to provide evidence for the existence of an Ordovician supra-subduction volcanic arc, either in the Midland Valley (accretionary model, with axially deflected turbidite flow) or offshore (back-arc model, with primary southern derivation). However, the age profile of detrital zircons from the Portpatrick Formation sandstones are typical of Gondwana and Avalonia, recording much older Neoproterozoic volcanism (U-Pb $557 \pm 6 \mathrm{Ma}$ and $613 \pm 12$ Ma; Phillips et al. 2003; also see Kelley \& Bluck 1989, 1990), rather than showing evidence for a contemporaneous volcanic arc. If the volcaniclastic detritus was indeed Avalonian it was introduced into the sedimentary basins developed marginal to Laurentian continent as early as the Caradoc, with profound implications for the palaeogeography of the Iapetus Ocean. An Avalonian source also fitted with isotope studies which showed that Grampian Terrane Dalradian Supergroup rocks were an unlikely source for the northerly derived, quartzofeldspathic units such as the broadly contemporaneous Kirkcolm Formation in the Southern Uplands. Smith et al. (2001) have suggested that one potential source of detritus for the northerly derived sandstones of the Ordovician northern part of the Southern Uplands terrane lay within the Midland Valley. However, the detrital zircon study of Waldron et al. (2008) has demonstrated that the late Ordovician sandstones of the northern belt of the Southern Uplands could well have been largely derived from a Laurentian source. This leaves the depositional setting and provenance of the Ordovician to Silurian strata of the Midland Valley terrane as poorly understood elements in the early Palaeozoic palaeogeography of the Scottish sector of the Iapetus Ocean.

The primary objective of this paper is to reassess the evolution of the Midland Valley terrane during the Early Palaeozoic in the light of laser ablation U-Pb ages obtained for the detrital zircon populations within the sandstones of the March Wood, Hareshaw Conglomerate, Parishholm Conglomerate, Cock Rig and Craigskelly Conglomerate formations. These data provide important age constraints on the source terrane which fed sediment into the sedimentary basins along the Laurentian continental margin.

\section{The Lower Palaeozoic strata of the Midland Valley terrane}


The Lower Palaeozoic sedimentary rocks of the Midland Valley terrane are mostly found close to its southern margin (Fig. 2). The Ordovician sequence only occurs in the southwest around Girvan and ranges from Llanvirn to Ashgill in age (Williams 1962; Ingham 1978; Stone \& Smellie 1988). It consists of a thick sequence of northwest-derived conglomerates, turbiditic sandstones and shallow water limestones which unconformably overlie the Tremadoc to Arenig Ballantrae ophiolitic complex. The Llanvirn to Caradoc sedimentary sequence includes the conglomeratic Kirkland, Benan and Kilranny formations which are interpreted as having been deposited in a proximal fore-arc basin to the Midland Valley volcanic arc, situated to the north, which was founded upon a basement of older (possibly Precambrian) metamorphic rocks intruded by granitic plutonic rocks (Bluck et al. 1980; Bluck 1984; Smith et al. 2001; Bluck et al. 2006). The Benan and Kilranny conglomerates are characterised by the presence of large granitic clasts which have yielded ages in the range 590 to 450 Ma (Rb-Sr; Longman et al. 1979), implying a prolonged period of granite intrusion. The source of these rocks is presently unknown as is the origin of an early Tremadoc limestone boulder described by Rushton \& Tripp (1979) from the Benan Conglomerate. The granitic clast content of the Benan Conglomerate has been related to granitic magmatism and uplift in the source area to the north, with the variation in thickness of the conglomerate being used as evidence for oblique slip on contemporaneous faults located along the northern margin of Iapetus (Ince, 1984). The older Kirkland Conglomerate is dominated by detritus derived from the Ballantrae ophiolitic complex, an obducted fragment of an arc/back-arc assemblage composed of serpentinised ultramafic rocks, gabbroic intrusions, and early Ordovician within-plate and island-arc lavas (including primitive island-arc tholeiites and boninites; see Smellie \& Stone 1992, 2001; Smellie et al. 1995), and volcaniclastic rocks (containing Arenig fossils, Stone \& Rushton 1983). This imbricated, suprasubduction zone ophiolitic assemblage was emplaced northwards onto the southern margin of the Midland Valley terrane in response to arc-continent collision and subsequent reversal in subduction polarity (Smellie \& Stone 2001) at the end of the Arenig (478 \pm 8 Ma; Bluck et al. 1980; Stone \& Rushton 2003). The Ordovician conglomeratic sedimentary rocks of the Girvan area were then deposited in a proximal, fore-arc basin to the postulated Midland Valley arc system that developed after the obduction of the Ballantrae complex, possibly during the Llanvirn, when 
subduction of the Iapetus Ocean lithosphere had been established beneath the Laurentian continental margin.

In the southern Midland Valley, Llandovery to Wenlock rocks crop out in a series of inliers (Fig. 2): (i) the Pentland Hills inliers; (ii) the south central inliers (Hagshaw Hills, Lesmahagow, Carmichael and Eastfield); and (iii) the Girvan inliers where the Silurian rocks unconformably overlie Ordovician strata. In general, the Silurian inliers record the transition from an older (Llandovery) transgressive marine sequence (including turbiditic sandstones) to a younger (Lower Wenlock) regressive terrestrial succession (Cocks \& Toghill 1973; Rolfe 1960, 1961; Rolfe \& Fritz 1966; Cameron \& Stephenson 1985; Robertson 1989; Smith 1995; Clarkson et al. 2001). Differences between the individual inliers in the thicknesses of the sequences and their detailed stratigraphy reflect deposition within a series of small, strike-slip subbasins developed oblique to the major northeast-trending Caledonian structural lineaments (Williams \& Harper 1988; Smith 1995; Phillips et al. 1998). This Lower Silurian sub-basin architecture continued into the Upper Silurian and controlled the deposition of the redbed fluviatile sandstones and alluvial fan conglomerates which form the lower part of the overlying (and partly Devonian) Lanark Group. Provenance studies, in particular Phillips et al. (2004), have shown that strata of the Silurian inliers and Siluro-Devonian Lanark Group sedimentary rocks were derived from the same source, which included volcanic and hypabyssal igneous rocks, a wacke sandstone-dominated sedimentary sequence, granitic plutonic rocks and older metamorphic rocks (also see McGiven 1967; Bluck 1983; Heinz \& Loeschke 1988; Syba 1989). Minor differences in sandstone composition between the inliers reflect the influence of the sub-basin architecture on sediment dispersal patterns. Palaeocurrent evidence shows that sources lay both to the north and south, leading to the conclusion that they were located within an originally much wider Midland Valley terrane (Bluck 1983, 1984; Smith 1995; Phillips et al. 1998). Apart from thin calcalkaline, rhyodacitic metabentonite beds (Batchelor \& Clarkson 1993) in the late Llandovery to early Wenlock succession of the Pentland Hills inlier, there is no unequivocal evidence of contemporaneous volcanism within the Lower Palaeozoic succession of the southern Midland Valley.

The remainder of the Lanark Group (Lower Devonian) was deposited in a linear, northeast-southwest-trending basin (the Lanark Basin; Bluck 1984, 2000) that developed during a phase of transtension that was accompanied by the eruption of 
Siluro-Devonian calc-alkaline volcanic rocks. Conglomerates within the SiluroDevonian sequence of the northeast Midland Valley (Strathmore Basin) contain a diverse suite of granitic clasts which yield ages of between 475-457 $\mathrm{Ma}(\mathrm{Rb}-\mathrm{Sr}$ muscovite-whole-rock; U-Pb monazite), as well as detritus derived from a 'cryptic greywacke source' located within the Midland Valley terrane (Haughton et al. 1990; Haughton \& Halliday 1991). Although metamorphic detritus derived from Neoproterozoic Dalradian rocks north of the Midland Valley terrane does occur within the Upper Silurian strata from the Strathmore Basin (Phillips et al. 1998), none has been recognised unequivocally within the sandstones of the Lanark Basin or older Silurian sub-basins (Phillips et al. 2004).

\section{Sandstone petrography and provenance}

Five samples of medium- to coarse-grained and granule sandstone from the Girvan, Hagshaw Hills, Eastfield and North Esk (Pentlands) inliers were selected for isotopic analysis (Figs. 2 and 3, and Table 1). The results quantify the spatial and temporal changes in sandstone provenance from Lower Llandovery to Mid-Wenlock times.

The medium- to very coarse-grained sandstones are texturally and compositionally immature rocks with a closely packed, grain-supported texture (Fig. 4). Although traces of chloritic, carbonate and/or clay cements are present, pressure solution during compaction is the main mode of cementation. The sandstones are typically composed of angular to subangular, low sphericity clasts of mono- and polycrystalline quartz, plagioclase and variably altered rock fragments (Table 2). Although the lithic fragments are largely composed of fine- to very fine-grained igneous rocks (basalt, aphyric to feldspar-phyric andesite, aphyric to quartz-feldsparphyric rhyolite/rhyodacite, trachytic rock, microgranite), there are also sedimentary (chert, mudstone, siltstone) and metasedimentary (quartzite, meta-quartz arenite, phyllite, metasandstone) rock fragments (Table 2). This clast assemblage is consistent with these sedimentary rocks having been derived from a recycled orogenic provenance, comprising an eroded volcanic or igneous complex with an associated sedimentary cover, founded upon an older metamorphic basement ( $c f$. Phillips et al. 2004). Minor differences in sandstone composition between the clastic sequences within the individual inliers are thought to record localised changes in the composition of the source terrane, and/or sediment dispersal patterns within individual sub-basins (Phillips et al. 2004). 
The Lower Llandovery Craigskelly Conglomerate Formation (c. $40 \mathrm{~m}$ thick in the Girvan inlier) consists of well-rounded pebbles, cobbles and boulders of mudstone, granite, jasper, chert, felsite, microgabbro, gabbro, serpentinite and quartz (Cameron et al. 1986). The interbedded sandstone (sample N5075, Table 2) contains a similar range of igneous rock fragments (including serpentinite and basalt), as well as detritus derived from sedimentary and metamorphic rocks. The northeast-derived, Upper Llandovery Cock Rig Formation (North Esk, Pentland Hills inlier) sandstone (N5071) is broadly similar in composition to the Craigskelly sandstone, though this younger sandstone lacks serpentinite lithic clasts and contains a slightly higher proportion of metasedimentary rock fragments (Table 2).

The Lower Wenlock Parishholm Conglomerate Formation (N5067) and MidWenlock Hareshaw Conglomerate Formation (N5068) sandstones (both from the Hagshaw Hills inliers) were derived from the southeast. Although the lithic-rich sandstones within both of these formations are compositionally similar to the Llandovery sandstones, they also contain minor, but significant, amounts of metamorphic (quartz-schist, quartzofeldspathic mylonite, metabasalt) and granitic (diorite/granodiorites, micrographic granite, microdiorite) rock fragments (Table 2). The southeast-derivation of the Parishholm and Hareshaw conglomerate formations indicates that the recycled orogenic provenance which supplied detritus to the Lower Palaeozoic sedimentary sequences of the southern Midland Valley terrane was much wider than the current area of the terrane and extended much further to the south. The Mid-Wenlock March Wood Formation (Eastfield inlier) sandstone (N5065) is the most fine grained of the sandstones analysed. The fluviatile sandstone sequence of the March Wood Formation contains conglomerate inter-beds with quartzite pebbles; the Formation's provenance may be expected to that of the Hareshaw Conglomerate, though the sequence is slightly younger in age (Fig. 3).

Zircon has been identified in all the sandstones (Table 2), occurring as: (i) large, rounded detrital grains; (ii) rounded, dusty looking crystals included within metasedimentary rock fragments; (iii) equant to rod-shaped, anhedral to subhedral crystals included within plagioclase and quartz, and more rarely muscovite and biotite; and (iv) equant to rod-shaped, faceted crystals within granitic lithic clasts.

\section{Zircon age data}


Data were collected using laser ablation multi-collector ICP-MS. Details of the analytical protocol and instrumental set-up can be found in Appendix 1.

A number of general observations can be made regarding the detrital zircon populations within the Llandovery to Wenlock sandstones of the Midland Valley (see Fig. 6): (i) detrital zircon populations present in all five samples, irrespective of stratigraphical age, comprise a younger, Lower Palaeozoic component and an older predominantly Mesoproterozoic component (Figs. 5 and 6); (ii) the Lower Palaeozoic contribution in general becomes progressively 'younger' as the depositional age of the host rock becomes stratigraphically younger (Fig. 6); (iii) the younger limit of the Mesoproterozoic detrital zircon population becomes slightly younger as the host rocks get stratigraphically younger (Fig. 6); and (iv) the contribution of zircons from Neoproterozoic and Archaean rocks to the Midland Valley Silurian sediment was consistent but relatively minor.

\section{Craigskelly Conglomerate Formation}

The younger component within the sandstone (N5075) from the Craigskelly Conglomerate Formation (Lower Llandovery, northwest-derived) is dominantly Arenig/Llanvirn (c. 475) (c. 30 Ma older than age of host sediment). The Lower Palaeozoic part of the detrital zircon population is thought to be dating the granitic to rhyolitic igneous component present within the Craigskelly Conglomerate Formation sandstone. The age of the Lower Palaeozoic detrital zircon population within this sandstone is comparable to the dates obtained from granitic boulders ( $\mathrm{Rb}-\mathrm{Sr}$ dates 470-560 Ma, Longman 1980; Longman et al. 1979) within the underlying Caradocian Benan and Kilranny conglomerate formations, which have a similar provenance petrographically.

The Craigskelly Conglomerate Formation sandstone also contains significant Mesoproterozoic peaks (c. 1020, 1170, 1370 Ma, Figs. 5a and 6a) and much smaller older Palaeoproterozoic (Figs. 5a and 6a) detrital zircon components. The Mesoproterozoic component is most abundant at c. 1000 Ma (Fig. 6a), but there are no younger Proterozoic zircons present.

\section{Cock Rig Formation}

Data obtained for the Cock Rig Formation sandstone (N5071) (Upper Llandovery, northeast-derived) in the Pentland Hills are broadly similar to that for the Craigskelly 
Conglomerate Formation deposited at the other end of the Midland Valley. Present are the younger Arenig (c. 485 Ma; Figs. 5b and 6b) and older Mesoproterozoic (1110, 1180, 1540 Ma; Figs. 5b and 6b) components and an minor Late Archaean (c. $2.7 \mathrm{Ga})$ component.

\section{Parishholm Conglomerate Formation}

The detrital population within the southeast-derived Parishholm Conglomerate Formation (Lower Wenlock, c. $428 \mathrm{Ma}$ ) has a range of younger detrital zircons from Arenig (c. 475 Ma; Figs. 5c and 6c). This sandstone (N5071) is, however, distinguished from the Llandovery sandstones by a greater contribution from Llandovery/Ashgill (c. 445 Ma; Fig. 6c) zircons; as well as by a restricted Mesoproterozoic component (peaks at c. 1011, 1050, 1170 Ma; Fig. 6c). The Parishholm sandstone also contains Palaeoproterozoic and Neoarchaean components. The Parishholm Conglomerate Formation is dominated by igneous detritus (see Table 2) suggesting that the Lower Palaeozoic component of the detrital zircon population is predominantly derived from a granitic to rhyolitic igneous source. The overall similarity in detrital zircon data from the Craigskelly, Cock Rig and Parishholm formation sandstones, combined with the results of the petrological provenance study, strongly suggests that the same/similar source which supplied detritus to the Silurian sandstones extended throughout the Midland Valley terrane.

\section{Hareshaw Conglomerate Formation}

In contrast to the Parishholm Conglomerate Formation, the southeast-derived Hareshaw Conglomerate (mid-Wenlock), is rich in metamorphic detritus which is apparently reflected in its detrital zircon population. Uniquely amongst the Silurian sandstones analysed, the Hareshaw sandstone (N5068) is dominated by Mesoproterozoic zircons (c. 965, 1020, 1050 Ma; Figs 5d and 6d). The much reduced Lower Palaeozoic component is Caradoc in age.

\section{March Wood Formation}

The sandstone (N5065) from the March Wood Formation, also mid-Wenlock (c. 426 Ma) but probably the youngest sandstone analysed (Fig. 3), shows a return to a broadly bimodal population comprising a Llandovery (c. $430 \mathrm{Ma}$ ) and Arenig/Llanvirn (c. 480 Ma; Figs. 5e and 6e) contribution and an older 
Mesoproterozoic (c. 1000-1800 Ma; Figs. 5e and 6e) component. The Llandovery influence is most pronounced within the March Wood Formation demonstrating the increase in the importance of this young/juvenile source within the mid-Silurian.

\section{Discussion}

Comparison of the zircon populations in the Midland Valley sandstones

Since the detrital zircon populations of the Midland valley sandstones (irrespective of stratigraphical age) possess a younger lower Palaeozoic component and older predominantly Mesoproterozoic component, there appears to be a common factor to the source areas, even though they were deposited by currents from different directions into different sub-basins (see Phillips et al. 1998, 2004). The sandstones were deposited in relatively small strike-slip sub-basins (Smith 1995; Phillips et al. 1998 ) and the source areas were probably less than $100 \mathrm{~km}$ distant. Erosion of horsts and rift shoulders was most likely to have contributed to the sub-basin fill. It is important to assess whether the zircon content of the samples is first cycle or recycled from pre-existing sedimentary sources.

The abundance of zircons of c. 1000 Ma suggests a Grenvillian source from Laurentia, but some models show that a Sveconorwegian source (Cawood et al. 2007; cf. the Telemarkian magmatic events in their fig. 4) could be a more likely for southerly derived material as Baltica is placed relatively close to the south of Laurentia at around $600 \mathrm{Ma}$ and again as Iapetus closed at around $450 \mathrm{Ma}$. The general lack of late Neoproterozoic ages (c. $557 \mathrm{Ma}$ ) eliminates an Avalonian source for the detritus being supplied to the Silurian basins of the Midland Valley. The southerly derived sandstones in the Midland Valley have a more varied zircon population than those derived from the north of this terrane. Besides the dominant Mesoproterozoic grains, the southern source also provided Palaeoproterozoic, Neoarchaean and Palaeoarchaean grains. Whereas, the northerly derived sandstones contain a restricted population, which in addition to the Mesoproterozoic grains includes only a few Neoarchaean grains with or without Palaeoproterozoic representatives. By comparison the March Wood Formation, with an undetermined source-direction, has a similar population to the northwest-derived Craigskelly Conglomerate and so was probably sourced from the north. Possibly this reflects a less deeply eroded "basement" in this northerly source area. 
The Parishholm Conglomerate and Hareshaw Conglomerate formations occur within the Hagshaw inlier and as such are likely to have shared a common source. The slightly older Parishholm Conglomerate, however, contains more felsic/acidic clasts of Llandovery-Arenig age. This situation might be expected in deposits derived from the unroofing of a source area in which arc-related rocks overlie a metamorphic basement.

The March Wood Formation could have been derived from a similar source to the Parishholm Conglomerate Formation, but is less likely to have come from the same source as the Hareshaw Conglomerate, which is of a similar age, but in a separate inlier/sub-basin.

Llandovery-age zircons are not detected in the Craigskelly, Cock Rig and Hareshaw formations, but are present in the Wenlockian Parishholm Conglomerate and March Wood formations. It is known from interbedded metabentonite layers that there was penecontemporaneous volcanism affecting the southern Midland Valley in the Silurian. The metabentonites are rhyodacitic and contain euhedral zircon among other minerals. They are recorded from, for example, the Wether Law Linn Formation (Upper Llandovery to Wenlock age) just above the Cock Rig Formation (Batchelor \& Clarkson 1993), and just below in the Llandovery Reservoir Formation (Batchelor 1999) of the Pentland Hills North Esk inlier (Fig. 3). A further metabentonite occurs within the Ree Burn Formation (Upper Llandovery), which lies just below the Parishholm Conglomerate in the Hagshaw Hills inlier (Batchelor 1999).

\section{Provenance of the Ordovician-Silurian sedimentary sequences} in the Midland Valley terrane

Detrital zircon populations within the Silurian sandstones sampled from the southern Midland Valley are bimodal and clearly record the input of sediment from two main sources; a Lower Palaeozoic source and an older, predominantly Mesoproterozoic, basement (Figs. 5 and 6), or alternatively as a result of the recycling of an older sedimentary sequence.

It has been argued that the uplift of metamorphic rocks of the Grampian terrane shed detritus across the Midland Valley, which was then deposited within the Southern Uplands sedimentary basin (Hutchison \& Oliver 1998; Oliver et al. 2000). Although metamorphic detritus derived from the Grampian terrane is a common component within the Siluro-Devonian sandstones and conglomerates of the northern 
Midland Valley (Haughton \& Bluck 1989; Phillips et al. 1998), no unequivocal lithologies derived from the Grampian, Northern Highlands and Hebridean terranes (Fig. 1) have been recognised within the Silurian inliers or Devonian (Old Red Sandstone facies) sandstones of the southern Midland Valley (Phillips et al. 2004). The metasedimentary rocks of the Neoproterozoic Dalradian Supergroup, which crop out extensively along the southern margin of the Grampian terrane, are typically wellendowed with Archaean and late Palaeoproterozoic zircons (Cawood et al. 2003, 2007). The age profile of the detrital zircon populations (see Figs. 5 and 6) present within the sandstones of the southern Midland Valley, with their scarcity of Archean and late Palaeoproterozoic ages, clearly demonstrate that the Grampian terrane did not supply detritus to these Ordovician-Silurian sedimentary basins. Instead, the 10001800 Ma component was largely derived from a Mesoproterozoic (Grenvillian) source not represented in the Dalradian. Haughton (1988) and Haughton et al. (1990) demonstrated that a so called 'cryptic source' within the central part of the Midland Valley terrane, which supplied material to the southerly derived Lower Devonian Crawton Group conglomerates of the Strathmore Basin in the northeast Midland Valley, included a block of older ( $>440 \mathrm{Ma})$ metamorphic rocks. Further evidence for a Grenvillian basement to the Midland Valley terrane is provided by the presence of Mesoproterozoic (906-1180 Ma, Davies et al. 1984; Halliday et al. 1984; Aftalion et al. 1984) upper amphibolite to granulite facies metamafite and garnet granulite/quartz granulite xenoliths of metasedimentary origin within the much younger, Carboniferous volcanic vents of the Midland Valley (see Upton et al. 1999). The older Palaeoarchean, Neoarchaean and Palaeoproterozoic components are subordinate and variable in distribution within the Silurian sandstones and may well be recycled from the proposed Grenvillian basement. Some of these components are also indicated in the xenoliths from the Partan Craig vent in East Lothian, i.e. zircons with primary ages of $>2.2 \mathrm{Ga}$ and probably 2.7 to $2.8 \mathrm{Ga}$ (Halliday et al. 1984).

The Lower Palaeozoic (Cambrian to Ordovician) detrital zircon component within the sandstones was largely derived from a igneous/volcanic source which included granitic, andesitic and felsitic rocks. Geochemical studies (Heinz \& Loeschke 1988) indicate that the fine-grained volcanic to hypabyssal igneous rocks belong to calc-alkaline to high-K suites, associated with a convergent plate margin, or continental area undergoing crustal extension. Detritus shed from this igneous source terrane forms a major component of the sandstones within the southern Midland 
Valley (Table 2; also see Phillips et al. 2004). Granitic boulders, which have a comparable age range (Rb-Sr age dates 470-560 Ma, Longman 1980; Longman et al. 1979) to this Lower Palaeozoic component, occur within the northerly derived Benan and Kilranny conglomerate formations. These conglomerates also contain detritus derived from the Ballantrae ophiolitic complex (Bluck 1983). Although older than the Craigskelly Conglomerate Formation, these Ordovician conglomerates form part of the same stratigraphical sequence and were, therefore, probably derived from the same volcanic/plutonic source. Sm-Nd isotopic provenance studies (Stone \& Evans 1995) have shown that the Craigskelly Conglomerate Formation possesses a much lower $\varepsilon N d(-8.5)$ than the Kilranny Conglomerate $(\varepsilon N d=+3.2)$. Stone \& Evans (1995) suggested that the stripping of the Ballantrae ophiolite complex, progressively exposing the underlying basement, could explain this variation. However, the Lower Palaeozoic detrital zircon component in the Craigskelly Conglomerate Formation sandstone includes calc-alkaline intrusive/volcanic rocks indicating that this simple unroofing model does not fully explain the observed variation in isotopic composition.

The age of the igneous component within the Silurian sandstones of the Midland Valley is significantly older than the depositional/stratigraphical age of the host sediments. This relationship does not fit with any model involving sediment being shed from a contemporaneous volcanic centre (i.e. the Midland Valley arc, Bluck 1983; Bluck et al. 2006), but is more consistent with the reworking of a preexisting volcanic/plutonic complex founded upon, or intruded into a Mesoproterozoic (Grenvillian) metamorphic basement. Such an interpretation is supported by the petrographic provenance study of Phillips et al. (2004) which demonstrated a recycled orogenic provenance for the Silurian sandstones.

Indirect evidence suggests that the volcanic/plutonic terrane may have been associated with, or covered by a wacke sandstone-dominated sedimentary sequence that also included minor shelf limestones. The south- to southeast-derived SiluroDevonian Greywacke Conglomerate Formation of the southern Midland Valley contains abundant pebbles and cobbles of wacke sandstone (McGiven 1967; Bluck 1983, 1984; Smith 1995). These clasts are lithologically distinct from the Lower Palaeozoic strata of the Southern Uplands (Syba 1989; Stone \& Evans 2001) and are generally thought to have been derived from within the Midland Valley terrane (Syba 1989; Smith 1995; Phillips et al. 2004). Sparse limestone pebbles in these Siluro- 
Devonian conglomerates (Swanshaw Sandstone and Greywacke Conglomerate formations) contain Mid-Ordovician conodonts (Pygodus anserinus Biozone; Armstrong \& Owen 2000; Smith 2000; Dean 2000). Similarly, rare limestone clasts within the Lower Devonian conglomerates (Crawton Group) of the northeast Midland Valley contain early Ordovician silicified brachiopod and crinoid remains (Ingham et al. 1985), and probable mid-Ordovician conodonts (Armstrong \& Owen 2000).

Phillips et al. (2004) noted that the range of lithologies with an igneous, sedimentary and metamorphic provenance in the Silurian to Lower Devonian sedimentary sequences of the southern Midland Valley is remarkably similar to the rock assemblage present within the Tyrone Igneous Complex and its Ordovician cover (Cooper \& Johnston 2004; Cooper \& Mitchell 2004). This igneous complex lies within an extension of the Midland Valley terrane in Ireland (see Fig. 1) and comprises: (a) an ophiolitic complex (the Tyrone Plutonic Group) composed mainly of gabbro and dolerite with minor basalt; and (b) an Arenig in age (c. $473 \mathrm{Ma}$, Cooper et al. 2008) arc-related, volcanic suite (Tyrone Volcanic Group) which includes basaltic pillow lavas, basic and intermediate tuffs and rhyolite (Hutton et al. 1985; Cooper \& Johnston 2004; Cooper et al. 2008). Recent studies show that the ophiolite was obducted around c. $475 \mathrm{Ma}$, after which northward directed subduction and the volcanic arc were established (Cooper et al. 2008; Chew et al. 2008). Arc-related intrusives, ranging in composition from tonalite, to diorite and granodiorite, through to granite, as well as their higher level intrusive equivalents, have yielded ages in the range 473-464 Ma (U-Pb zircon, Hutton et al. 1985; Cooper et al. 2008). Biostratigraphical control on the age of the Tyrone Volcanic Group is limited to one stratigraphical horizon towards the top of the sequence on Slieve Gallion. Analysis of the graptolite fauna allowed Cooper et al. (2008) to establish a tight correlation to the Middle Arenig (late Castlemainian stage) for this part of the volcanic arc. Graptolite assemblages within the Balcreuchan Group of the Ballantrae Ophiolitic Complex on the southern margin of the Midland Valley terrane indicate that it is has a wider age range, from basal to upper Arenig (Stone \& Rushton 1983). Cooper et al. (2008) noted that the ophiolitic assemblage in the Ballantrae Complex includes serpentinised mantle rocks from deeper within the ophiolite sequence than the upper crustal (oceanic) gabbroic Tyrone Plutonic Group. It is likely, therefore, that the local Ballantrae Complex was the source of serpentinite within the Craigskelly Conglomerate Formation and the older Kirkland, Kilranny and Benan conglomeratic 
formations of the Girvan area. The age profile of the Lower Palaeozoic volcanic and plutonic components within the Craigskelly, Cock Rig, Parishholm and March Wood formation sandstones corresponds to the age of the Tyrone Volcanic Group supporting the hypothesis that this arc-related suite is representative of the source terrane that supplied detritus to the Ordovician-Silurian sedimentary basins of the southern Midland Valley.

The Tyrone Igneous Complex is believed to be faulted against and possibly thrust over the Tyrone Central Inlier (Corvanaghan Formation) which is composed of a sequence of high-grade (garnet \pm sillimanite) metasedimentary rocks similar to those of the Moine Group present in the Northern Highlands terrane of Scotland (Cooper \& Johnston 2004). A recent study of the metasedimentary rocks of the Tyrone Central Inlier (below the Tyrone Igneous Complex) (Chew et al. 2008) dated leucosomes at 467+/-12 Ma, and the main fabric biotite cooling age at 468+/-1.4 Ma confirming that the rocks were metamorphosed to sillimanite grade during the Grampian orogeny. These metamorphic rocks also yield Palaeoproterozoic Sm-Nd model ages and detrital zircons with populations at 1.05-1.2. 1.5, 1.8, 2.7 and $3.1 \mathrm{Ga}$. Chew et al. (2008) noted that, besides the zircon population in the 1 to 1.8 Ga range, the significant population between 2.5 and $2.7 \mathrm{Ga}$ indicated that a correlation with either the Argyll Group or the Southern Highland Group of the Dalradian Supergroup was most likely. They concluded that the Tyrone Central Inlier was a Laurentian microcontinent incorporated into an outboard volcanic arc terrane during the Grampian orogeny. This raises the possibility that the population of mainly 1 to 1.7 Ga detrital zircons in the Midland Valley Silurian sandstones is from another basement or microcontinental source with a Grenvillian signature, possibly even the Moine (Northern Highlands terrane) or Grampian Group (Grampian terrane) (Cawood et al. 2007).

The age profiles of detrital zircon populations present in the Silurian sandstones of the southern Midland Valley do not fit with a simple model of unroofing of a pre-existing, Tyrone-like, complex. The age of the Lower Palaeozoic component in the sandstones, in general, becomes progressively younger stratigraphically upward through the sequence (Fig. 6), with the nature of the profiles indicating that detritus was simultaneously being supplied from both the volcanic/plutonic complex and basement rocks. A regional correlation has previously 
been made between the Tyrone Igneous and Ballantrae complexes (see Cooper et al. 2008 and references therein). Both of these complexes were accreted/obducted onto the SE-margin of the Laurentian continent during the Arenig, but occur on opposite sides of the Midland Valley terrane. If they originally formed part of the same arcophiolite complex then it has been dismembered during the subsequent closure of the Iapetus Ocean, probably as a result of oblique transpression focused along the southern margin of Laurentian (Soper et al. 1992). Williams \& Harper (1988), Smith (1995) and Phillips et al. (1998) have all concluded that sinistral strike-slip controlled basin development, sedimentary facies distribution and deformation along the southern side of the Midland Valley terrane from the Llandovery through to at least early Devonian times. This prolonged period of strike-slip deformation would not only have led to the dismemberment of the Tyrone Igneous and Ballantrae complexes, but also the periodic uplift and erosion of different structural/stratigraphic levels within this ophiolite/arc-related assemblage. Sediment shed from these uplifted blocks could have included all of the required mix of volcanic, plutonic and basement derived lithologies recognised within the sedimentary sequences of the southern Midland Valley. The remains of this dismembered volcanic/plutonic source, apart from the Tyrone Igneous and Ballantrae complexes, are now hidden beneath the locally thick lower to upper Palaeozoic cover sequence which blankets the Midland Valley terrane.

\section{Implications for sediment dispersal patterns within the Scottish sector of the Caledonian orogen}

It is clear from the above discussion that the likely source of the Lower Palaeozoic sedimentary sequences preserved along the southern margin of the Midland Valley was located within this elongate northeast-southwest-trending terrane. Furthermore, the absence of detritus derived from the Grampian terrane Dalradian Supergroup, situated to the north, questions any model requiring sediment dispersal across the Midland Valley terrane to feed the Southern Uplands sedimentary basin. Tanner \& Sutherland (2007) have argued that the Highland Boundary Fault, which separates the Grampian and Midland Valley terranes, does not represent a major terrane boundary. Consequently, these two areas may have been in relatively close proximity during the Lower Palaeozoic, requiring that any sediment supplied to the Southern Upland 
sedimentary basin from the Grampian terrane must have by-passed the Midland Valley (Fig. 7).

The northerly derived conglomerates and wacke sandstones within the Ordovician Northern Belt of the Southern Uplands terrane, contain granite clasts (c. $470 \mathrm{Ma}$; Elders 1987; Bluck et al. 2006), detrital micas $\left({ }^{40} \mathrm{Ar}^{3}{ }^{39} \mathrm{Ar}\right.$ cooling ages in the range 458-502 Ma; Kelley \& Bluck 1989) and detrital garnet (Sm-Nd age c. $468 \mathrm{Ma}$; Oliver et al. 2000) which suggest a source within the Laurentian continent (see Smith et al. 2001; Phillips et al. 2003). The range of lithologies present within the conglomeratic rocks (e.g. Corsewall and Blackcraig conglomerates) of the Ordovician Corsewall and Marchburn formations of the Northern Belt of the Southern Uplands are similar to those found within the coarse clastic deposits in the Girvan area of the southern Midland Valley. This led Smith et al. (2001) to conclude that the source of the northerly derived sediments within the Northern Belt lay within the Midland Valley terrane, and included the Ballantrae and Tyrone Igneous complexes (Fig. 7). Transported fossils (e.g. Kilbuchophyllid corals) present within the Southern Uplands conglomerates (Kirkcolm Formation) are similar to the fauna present within the Caradocian mudstones and limestones of County Tyrone, Ireland (Bardahessiagh Formation, Pomeroy, Scrutton et al. 1998), providing further evidence that the Midland Valley terrane, at least intermittently, supplied material to the Southern Uplands sedimentary basin (see Fig. 7). However, although the detrital zircon population within the sandstones of the Kirkcolm Formation includes a significant Mesoproterozoic (peak at c. $1050 \mathrm{Ma}$ ) component, the formation is dominated by zircons derived from a Palaeoproterozoic (or older) source terrane. This does not fit with the Midland Valley being the sole source for the Kirkcolm Formation, but indicates a significant input of detritus from Laurentia. Oliver et al. (2000) suggested that metamorphic detritus (including garnet) within the sandstones of the Southern Uplands was derived from the uplifted Grampian terrane (also see Hutchison \& Oliver 1998). The predominantly northeast to southwest palaeoflow direction established for a large part of the wacke sandstone sequence in the Northern Belt (evidence summarised in Smith et al. 2001) raises the possibility that any detritus derived from the Grampian terrane may have by-passed the Midland Valley to the north, to be transported axially along the Southern Upland sedimentary basin (Fig. 7). Work by Phillips et al. (2003) dating detrital zircons (U-Pb, $557 \mathrm{Ma}, 613 \mathrm{Ma}$ and $1043 \mathrm{Ma}$ ) from the southwest-derived Portpatrick Formation (Caradoc) was interpreted in terms 
of a provenance for relatively fresh arc-related volcanic detritus within an Avalonian continent fragment located near to the southern margin of Laurentia (Fig. 7).

It is clear from the above that provenance and sediment dispersal patterns within the Scottish sector of the Caledonian orogen are far more complex than previously thought. The broadly Arenig in age, obducted ophiolite, arc-related, volcanic-plutonic complex and Mesoproterozoic basement which provided a major source of detritus to Caradoc sedimentary basins in the Midland Valley and also provided some detritus into the Southern Uplands basin, was located within the Midland Valley terrane. Evidence for Caradoc volcanism within the Midland Valley is lacking, questioning the reality of active arc-related volcanism within this terrane related to subduction and initiation of the Southern Uplands accretionary complex (McKerrow et al. 1977; Bluck et al. 1980; Leggett et al. 1982; Bluck 1983). The potential sedimentary links between the Midland Valley and Southern Uplands terrane have implications for the magnitude of strike-slip displacement accommodated by the northeast-trending, tract-bounding faults within the Northern Belt of the Southern Uplands (see Fig. 7). The Southern Upland-Stinchar Valley Fault is widely considered to be a major terrane boundary separating the Midland Valley and Southern Upland terranes (e.g. Elders 1987). The presence of Midland Valley-derived detritus within the Corsewall and Marchburn formations (Tappins Group, Smith et al. 2001) immediately to the south of this fault system, indicates that the Midland Valley terrane and northern part of the Southern Upland terrane were in relatively close proximity during the early Caradoc. Consequently, the amount of sinistral strike-slip movement accommodated by the Southern Upland-Stinchar Valley Fault system may have been relatively small, possibly less than a hundred kilometres. The 'Midland Valley influence' on the provenance of the Kirkcolm, Portpatrick and Shinnel formations decreases southward, away from this terrane, consistent with a more 'remote' site of deposition within the Southern Uplands sedimentary basin. The present relatively close proximity of these sand-rich formations to the Midland Valley terrane, requires an increase in the amount of strike-slip displacement accommodated by other tract-bounding faults within the Northern Belt of the Southern Uplands (see Fig. 7). The Leadhills and Fardingmullach faults represent major structures within the Southern Uplands accretionary complex, and may, therefore, have accommodated a significant proportion of this movement. Further to the south, the Orlock Bridge Fault forms the boundary between the Northern (Ordovician) and Central (Silurian) belts of 
the Southern Uplands terrane (Anderson \& Oliver 1986; Phillips et al. 1995; Barnes et al. 1995). In southwest Scotland, this brittle fault is associated with an up to $5 \mathrm{~km}$ wide sinistral ductile shear zone, the Moniaive Shear Zone (Phillips et al. 1995), movement along which occurred during the mid-Wenlock (Barnes et al. 1995; Smith et al. 2001). Continued sinistral strike-slip deformation along the tract-bounding faults would have resulted in the progressive 'telescoping' of the Southern Uplands (Ordovician) sedimentary basin, and its accretion onto the southern margin of the Midland Valley terrane. This progressive collapse of the basin is thought to have occurred in response to overall sinistral transpression focused along the southern margin of the Laurentian continent (Barnes et al. 1995) during the final stages of Iapetus Ocean closure.

\section{Conclusions}

Sandstones from the Silurian sequences of the southern Midland Valley are compositionally similar, similar in the age distribution of their detrital zircon populations and were derived from a recycled orogenic provenance. Detrital zircon populations within the sandstones, irrespective of stratigraphical age, are dominated by a younger, early Palaeozoic and an older predominantly Mesoproterozoic component. The youngest early Palaeozoic zircons present become progressively younger upward through the sequence, but is dominated by Arenig/Llanvirn zircons dominate and are interpreted as having been derived from a pre-existing volcanicplutonic-ophiolite source located within the Midland Valley. The younger zircons of Llanvirn to Llandovery age in the Hagshaw Hills, and Llandovery age in the Eastfield inlier are interpreted as indicative of penecontemporaneous, but less intense, magmatic events associated with the development of strike-slip basins. The Mesoproterozoic component within the sandstones has a dominant component at $\mathrm{c}$. $1000 \mathrm{Ma}$ and is thought to represent metamorphic detritus shed from a Grenvillian basement to the Midland Valley terrane.

No evidence has been found to suggest that a Grampian metamorphic terrane supplied sediment to the Ordovician-Silurian basins located along the southern margin of the Midland Valley: viz, there are no Archaean and c. $1.8 \mathrm{Ga}$ 'spikes'. This questions any model requiring the transport of detritus across the Midland Valley, to be deposited within the Southern Uplands sedimentary basin from Lower Llandovery to Wenlock times. The Arenig age obtained for a significant proportion of the Lower 
Palaeozoic detrital zircon population has led to the conclusion that an assemblage equivalent to the Ballantrae Complex and Tyrone Igneous Complex, and their associated cover sequences, formed part of the source. The age profiles of detrital zircon populations, however, do not fit with a simple model of unroofing of such a complex, rather they point to the periodic uplift of fault-bound dismembered blocks during a prolonged (Llandovery through to at least early Devonian) period of sinistral strike-slip deformation which controlled basin development, sedimentary facies distribution and deformation along the southern side of the Midland Valley terrane.

\section{Acknowledgements}

This work forms part of the British Geological Survey's Geology and Landscape North Programme. Maxine Akhurst, Hugh Barron an Mark Cooper are acknowledged for helpful discussions and comments on earlier versions of this paper. It is published with the permission of the Executive Director, British Geological Survey (National Environmental Research Council).

\section{References}

AFTALION, M., VAN BREEMEN, O. \& BOWES, D.R. 1984. Age constraints on basement of the Midland Valley of Scotland. Transactions of the Royal Society of Edinburgh: Earth Sciences. 75, 53-64.

ANDERSON, T.B. \& OLIVER, G.J.H. 1986. The Orlock Bridge Fault: a major Late Caledonian sinistral fault in the Southern Uplands terrane, British Isles. Transactions of the Royal Society of Edinburgh: Earth Sciences. 77, 203-222.

ARMSTRONG, H.A. \& OWEN, A.W. 2000. Age and provenance of limestone clasts in Lower Old Red Sandstone conglomerates: implications for the geological history of the Midland Valley Terrane. In FRIEND, P.F. \& WILLIAMS, B.P.J. (eds.) New Perspectives on the Old Red Sandstone. Geological Society of London, Special Publication. 180, 459-472.

ARMSTRONG, H.A. \& OWEN, A.W. 2001. Tectonic evolution of the paratectonic Caledonides of northern Britain. Journal of the Geological Society of London. 158, 475-486. 
ARMSTRONG, H.A., OWEN, A.W., SCRUTTON, C.T., CLARKSON, E.N.K. \& TAYLOR, C.M. 1996. Evolution of the Northern Belt, Southern Uplands: implications for the Southern Uplands controversy. Journal of the Geological Society of London. 153, 197-205.

BATCHELOR, R. A. 1999. Metabentonites from the Silurian inliers of the southern Midland Valley of Scotland: distribution and geochemistry. Scottish Journal of Geology. 35, 71-77.

BATCHELOR, R.A. \& CLARKSON, E.N.K. 1993. Geochemistry of a Silurian metabentonite and associated apatite from the North Esk Inlier, Pentland Hills. Scottish Journal of Geology. 29, 123-30.

BARNES, R.P, PHILLIPS, E.R. \& BOLAND, M.P. 1995. The Orlock Bridge Fault in the Southern Uplands of southwestern Scotland: a terrane boundary? Geological Magazine. 132, 523-529.

BLEINER \& GUNTHER. 2001. Theoretical description and experimental observation of aerosol transport processes in laser ablation inductively coupled plasma mass spectrometry. Journal of Analytical At. Spectrometry. 16, 449-456.

BLUCK, B.J. 1983. Role of the Midland Valley of Scotland in the Caledonian orogeny. Transactions of the Royal Society, Edinburgh: Earth Sciences. 74, 119-136.

BLUCK, B.J. 1984. Pre-Carboniferous history of the Midland Valley of Scotland. Transactions of the Royal Society, Edinburgh: Earth Sciences. 75, 275-296.

BLUCK, B.J. 2000. Old Red Sandstone basins and alluvial systems of Midland Scotland. In FRIEND, P.F. \& WILLIAMS, B.P.J. (eds.) New Perspectives on the Old Red Sandstone. Special Publication of the Geological Society of London. 180, 417437. 
BLUCK, B.J., HALLIDAY, A.N., AFTALION, M. \& MACINTYRE, R.M. 1980. Age and origin of Ballantrae ophiolite and its significance to the Caledonian orogeny and Ordovician time scale. Geology, 9, 331-333.

BLUCK, B.J., GIBBONS, W. \& INGHAM, J.K. 1992. Terranes. In COPE, J.C.W. INGHAM, J.K. \& RAWSON, P.F. (eds.) Atlas of palaeogeography and lithofacies. Geological Society of London, Memoir. 13, 1-3.

BLUCK, B.J. DEMPSTER, T.J., AFTALION, M., HAUGHTON, P.D.W. \& ROGERS, G. 2006. Geochronology of a granitoid boulder from the Corsewall Formation (Southern Uplands): implications for the evolution of southern Scotland. Scottish Journal of Geology. 42, 29-35.

CAMERON, I.B. \& STEPHENSON, D. 1985. British Regional Geology: The Midland Valley of Scotland (third edition). British Geological Survey, HMSO.

CAMERON, I.B., STONE, P. \& SMELLIE, J. 1986. Geology of the country around Girvan. Explanation for 1:50 000 geological sheet 7 (Scotland). British Geological Survey, HMSO.

CAWOOD, P. A., NEMCHIN, A.A., SMITH, M. \& LOEWY, S. 2003. Source of the Dalradian Supergroup constrained by $\mathrm{U} / \mathrm{Pb}$ dating of detrital zircon and implications for the East Laurentian margin. Journal of the Geological Society, London. 160, 231246.

CAWOOD, P.A., NEMCHIN, A.A., STRACHAN, R., PRAVE, T. \& KRABBENDAM, M. 2007. Sedimentary basin and detrital zircon record along East Laurentia and Baltica during assembly and breakup of Rodinia. Journal of the Geological Society of London. 164, 257-275.

CHEW, D.M.., FLOWERDEW, M.J., PAGE, L.M., CROWLEY, Q.G., DALY, J.S., COOPER, M. \& WHITEHOUSE, M.J. 2008. The tectonothermal evolution and provenance of the Tyrone Central Inlier, Ireland: Grampian imbrication of an 
outboard Laurentian microcontinent? Journal of the Geological Society, London. 165, 675-685.

CLARKSON, E.N.K., HARPER, D.A.T. \& TAYLOR, C.M. 2001. Scottish Silurian Shorelines. Transactions of the Royal Society of Edinburgh: Earth Sciences. 91, 479487.

COCKS, L.R.M. \& TOGHILL, P. 1973. The biostratigraphy of the Silurian rocks of the Girvan district, Scotland. Journal of the Geological Society of London. 129, 20943.

COOPER, M.R. \& JOHNSTON, T.P. 2004. Central Highlands (Grampian) Terrane Metamorphic Basement. In MITCHELL, W.I. (ed.) The Geology of Northern Ireland $\left(2^{\text {nd }}\right.$ Edition). Geological Survey of Northern Ireland, Belfast.

COOPER, M.R., CROWLEY, Q.G. \& RUSHTON, A.W.A. 2008. New age constraints for the Ordovician Tyrone Volcanic Group, Northern Ireland. Journal of the Geological Society of London. 165, 333-339.

DALY, J.S. 1996. Pre-Carboniferous history of the Annagh Gneiss Complex, Northwestern Ireland, and correlation with Laurentia-Baltica. Irish Journal of Earth Sciences. 74, 5-18.

DAVIES, G.R., UPTON, B.G.J. \& STROGEN, P. 1984. Sr and Nd isotope evidence for age and origin of crustal xenoliths from the Midland Valley of Scotland and central Ireland. Transactions of the Royal Society of Edinburgh: Earth Sciences. 75, 297.

DEAN, M. 2000. Preliminary report on the conodonts biostratigraphy of a limestone 'pebble' in a conglomerate at Croy Foreshore, Ayrshire. British Geological Survey, Technical Report. WH/00/10R. 
ELDERS, C.F. 1987. The provenance of granite boulders in conglomerates of the Northern and Central Belts of the southern Uplands of Scotland. Journal of the Geological Society of London. 144, 853-863.

EVANS, J.A., STONE, P. \& FLOYD, J.D. 1991. Isotopic characteristics of Ordovician greywacke provenance in the Southern Uplands of Scotland. In MORTON, A.C., TODD, S.P. \& HAUGHTON, P.D.W. (eds.) Developments in Sedimentary Provenance Studies. Geological Society of London, Special Publication. 57, 161-172.

HAUGHTON, P.D.W. 1988. A cryptic Caledonian flysch terrane in Scotland. Journal of the Geological Society, London. 145, 685-703.

HAUGHTON, P.D.W. \& BLUCK, B.J. 1989. Diverse alluvial sequences from the Lower Old Red Sandstone of the Strathmore region, Scotland - implications for relationship between late Caledonian tectonics and sedimentation. Proceedings of the $2^{\text {nd }}$ international symposium on the Devonian system. Canadian Society of Petroleum Geologists, Memoir. 14, 269-293.

HAUGHTON, P.D.W., ROGERS, G. \& HALLIDAY, A.N. 1990. Provenance of Lower Old Red Sandstone conglomerates, SE Kincardineshire: evidence for the timing of Caledonian terrane accretion in central Scotland. Journal of the Geological Society, London. 147, 105-120.

HAUGHTON, P.D.W. \& HALLIDAY, A.N. 1991. Significance of late Caledonian igneous complex revealed by clasts in the Lower Old Red Sandstone conglomerates, central Scotland. Geological Society of America Bulletin. 103, 1476-92.

HALliDAY, A.N., AFTALION, M., UPTON, B.G.J., ASPEN, P. \& JOCELYN, J. 1984. U-Pb isotopic ages from a granulite-facies xenolith from Parten Craig in the Midland Valley of Scotland. Transaction of the Royal Society of Edinburgh; Earth Sciences. 75, 71-74. 
HEINZ, W. \& LOESCHKE, J. 1988. Volcanic clasts in Silurian conglomerates of the Midland Valley (Hagshaw Hills inlier) Scotland, and their meaning for Caledonian plate tectonics. Geologische Rundschau. 77, 453-66.

HUTTON, D.H.W., AFTALION, M. \& HALliDAY, A.N. 1985. An Ordovician ophiolite in County Tyrone, Ireland. Nature. 315, 210-212.

HUTCHINSON, A.R. \& OLIVER, G.J.H. 1998. Garnet provenance studies, juxtaposition of Laurentian marginal terranes and timing of the Grampian Orogeny in Scotland. Journal of the Geological Society of London. 155, 541-550.

INCE, D. 1984. Sedimentation and tectonism in the Middle Ordovician of the Girvan district, SW Scotland. Transactions of the Royal Society of Edinburgh: Earth Sciences. 75, 225-237.

INGHAM, J K. 1978. Geology of a continental margin 2: middle and late Ordovician transgression, Girvan. In BOWES, D.R. \& LEAKE, B.E (eds.) Crustal evolution in northwestern Britain and adjacent regions. Geological Journal Special Issue. 10, 163 167.

INGHAM, J.K, CURRY, G.B \& WILLIAMS, A. 1985. Early Ordovician Dounans Limestone fauna, Highland Border Complex, Scotland. Transactions of the Royal Society of Edinburgh: Earth Sciences. 76, 481-513.

KELLEY, S. \& BLUCK, B.J. 1989. Detrital mica ages from the Southern Uplands using Ar-Ar laser probe. Journal of the Geological Society of London. 146, 401-403.

KELLEY, S. \& BLUCK, B.J. 1990. Discussion on detrital mica ages from the Southern Uplands using Ar-Ar laser probe. Journal of the Geological Society of London. 147, 882-884.

KNELLER, B.C. 1991. A foreland basin on the southern margin of Iapetus. Journal of the Geological Society, London. 148, 207-210. 
KNELLER, B.C., KING, L.M. \& BELL, A.M. 1993. Foreland basin development and tectonics on the northwest margin of eastern Avalonia. Geological Magazine. 130, 691-697.

LAMBERT, R. St J. \& MCKERROW, W.S. 1976. The Grampian Orogeny. Scottish Journal of Geology. 12, 271-92.

LEGGETT, J.K. 1987. The Southern Uplands as an accretionary prism: the importance of analogues in reconstructing palaeogeography. Journal of the Geological Society, London. 144, 737-52.

LEGGETT, J.K. 1980 The sedimentological evolution of a Lower Palaeozoic accretionary fore-arc in the Southern Uplands of Scotland. Sedimentology. 27, 401417.

LEGGETT, J.K., McKERROW, W.S. \& EALES, M. 1979. The Southern Uplands of Scotland; a Lower Palaeozoic accretionary prism. Journal of the Geological Society, London. 136, 755-70.

LONGMAN, C.D. 1980. Age and affinities of granitic detritus in Lower Palaeozoic conglomerates, SW Scotland. PhD thesis, University of Glasgow, UK.

LONGMAN, C.D., BLUCK, B.J. \& VAN BREEMAN, O. 1979. Ordovician conglomerates and the evolution of the Midland Valley. Nature. 280, 578-581.

LONGMAN, C.D., BLUCK, B.J., VAN BREEMAN, O. \& AFTALION, M. 1982. Ordovician conglomerates: constraints on the timescale. In ODIN, G.S. (ed.) Numerical dating in stratigraphy. Wiley, New York. 807-809

MCKERROW, W.S., LEGGETT, J.K. \& EALES, M.H. 1977. Imbricate thrust model of the Southern Uplands. Nature. 267, 237-9.

McGIVEN, A. 1967. Sedimentation and provenance of post-Valentian conglomerates up to and including the basal conglomerate of the Lower Old Red sandstone in the 
southern part of the Midland Valley of Scotland. PhD Thesis, University of Glasgow, U.K.

MORRIS, J.H. 1987. The Northern Belt of the Longford-Down, Ireland and Southern Uplands, Scotland: an Ordovician back-arc basin. Journal of the Geological Society, London. 144, 773-786.

NEEDHAM, D.T. 2004. Deformation in Moffat Shale detachment zones in the western part of the Scottish Southern Uplands. Geological Magazine. 141, 441-453.

OLIVER, G.J.H., CHEN, F., BUCHWALDT, R. \& HEGNER, E. 2000. Fast tectonometamorphism and exhumation in the type area of the Barrovian and Buchan zones. Geology. 28, 459-462.

PHILLIPS, E.R., BARNES, R.P., BOLAND, M.P., FORTEY, N.J. \& McMILLAN, A.A. 1995. The Moniaive Shear Zone: a major zone of sinistral strike-slip deformation in the Southern Uplands of Scotland. Scottish Journal of Geology. 31, 139-149.

PHILLIPS, E.R., SMITH, R.A. \& CARROLL, S. 1998. Strike-slip, terrane accretion and the pre-Carboniferous evolution of the Midland Valley of Scotland. Transactions of the Royal Society of Edinburgh: Earth Sciences. 89, 209-224.

PHILLIPS, E.R., EVANS, J.A., STONE, P., HORSTWOOD, M.S.A., FLOYD, J.D., SMITH, R.A., AKHURST, M.C. \& BARRON, H.F. 2003. Detrital Avalonian zircons in the Laurentian Southern Uplands terrane, Scotland. Geology. 31, 625-628.

PHILLIPS, E.R., BARRON, H.F., SMITH, R.A. \& ARKLEY, S. 2004. Composition and provenance of the Silurian to Devonian sandstone sequences of the southern Midland Valley. Scottish Journal of Geology. 40, 23-42.

ROBERTSON, G. 1989. A palaeoenvironmental interpretation of the Silurian rocks of the Pentland Hills, near Edinburgh. Transactions of the Royal Society of Edinburgh: Earth Sciences. 80, 127-41. 
ROLFE, W.D.I. 1960. The Silurian inlier of Carmichael, Lanarkshire. Transactions of the Royal Society of Edinburgh: Earth Sciences. 64, 240-69.

ROLFE, W.D.I. 1961. The geology of the Hagshaw Hills Silurian inlier, Lanarkshire. Transactions of the Edinburgh Geological Society. 18, 240-69.

ROLFE, W.D.I. \& FRITZ, M.A. 1966. Recent evidence for the age of the Hagshaw Hills inlier, Lanarkshire. Scottish Journal of Geology. 18, 240-69.

RUSHTON, A.W.A. \& TRIPP, R.P. 1979. A fossilferous lower Canadian (Tremadoc) boulder from the Benan conglomerate of the Girvan district. Scottish Journal of Geology. 15, 321-327.

SCRUTTON, C.T., JERAM, A.J. \& ARMSTRONG, H.A. 1998. Kilbuchophyllid corals from the Ordovician (Caradoc) of Pomeroy, Co. Tyrone: implications for coral phylogeny and for movement on the Southern Uplands Fault. Transactions of the Royal Society of Edinburgh: Earth Sciences. 88, 117-126.

SMELLIE, J.L. \& STONE, P. 1992. Geochemical control on the evolutionary history of the Ballantrae Complex, SW Scotland, from comparisons with recent analogues. In PARSONS, L.M., MURTON, B.J. \& BROWNING, P. (eds.) Ophiolites and their Modern Oceanic Analogue. Geological Society of London, Special Publication. 60, 171-178.

SMELLIE, J.L. \& STONE, P. 2001. geochemical characteristics and geotectonic setting of early Ordovician basalt lavas in the Ballantrae Complex ophiolite, SW Scotland. Transactions of the Royal Society of Edinburgh: Earth Sciences. 91, 539555.

SMELLIE, J.L., STONE, P. \& EVANS, J.A. 1995. Petrogenesis of boninites in the Ordovician Ballantrae Complex ophiolite, S.W. Scotland. Journal of Volcanology and Geothermal Research. 69, 323-342. 
SMITH, R.A. 1995. The Siluro-Devonian evolution of the southern Midland Valley of Scotland. Geological Magazine. 132, 503-13.

SMITH, R.A. 2000. Geology of the Croy area. Explanation of 1:10 000 Sheet 21SE/SW. Part of 1:50 000 Sheet 14 (Ayr). British Geological Survey, Technical Report. WA/00/13.

SMITH, R.A., PHILLIPS, E.R., FLOYD, J.D., BARRON, H.F. \& PICKETT, E.A. 2001. The Northern Belt 100 years on: a revised model of the Ordovician tracts near Leadhills, Scotland. Transactions of the Edinburgh Geological Society; Earth Sciences. 91, 421-434.

SOPER, N.J., STRACHAN, R.A., HOLDSWORTH, R.E., GAYER, R.A. \& GREILING, R.O. 1992. Sinistral transpression and the Silurian closure of Iapetus. Journal of the Geological Society, London. 149, 871-80.

STONE, P \& MERRIMAN, R.J. 2004. Basin thermal history favours an accretionary origin for the Southern Uplands terrane, Scottish Caledonides. Journal of the Geological Society, London. 161, 829-836.

STONE, P. \& SMELliE, J.L. 1988. Classical areas of British Geology; the Ballantrae area; a description of the solid geology of parts of 1:25 000 sheets NX 08, 18 and 19. HMSO for the British Geological Survey.

STONE, P. \& EVANS, J.A. 1995. Nd isotope study of provenance patterns across the British sector of the Iapetus Suture. Geological Magazine. 132, 571-580.

STONE, P. \& EVANS, J.A. 2001. Silurian provenance variation in the Southern Uplands terrane, Scotland, assessed using neodymium isotopes and linked with regional tectonic evolution. Transactions of the Royal Society of Edinburgh: Earth Sciences. 91, 447-455. 
STONE, P. \& RUSHTON, A.W.A. 1983. Graptolite faunas from the Ballantrae ophiolite complex and their structural implications. Scottish Journal of Geology. 19, 297-310.

STONE, P. \& RUSHTON, A.W.A. 2003. A Late Arenig (lower Yapeenian) graptolite fauna and the coeval tectonic development of the Ballantrae Complex ophiolite, SW Scotland. Scottish Journal of Geology. 39, 29-40.

STONE, P., FLOYD, J.D., BARNES, R.P. \& LINTERN, B.C. 1987. A sequential back-arc and foreland basin thrust duplex model for the Southern Uplands of Scotland. Journal of the Geological Society, London. 144, 753-64.

SYBA, E. 1989. The sedimentation and provenance of the Lower Old Red Sandstone Greywacke Conglomerate, southern Midland Valley, Scotland. PhD Thesis, University of Glasgow, UK.

TANNER, P.W.G. \& SUTHERLAND, S. 2007. The Highland Border Complex, Scotland: a paradox resolved. Journal of the Geological Society, London. 164, 111116.

UPTON, B.J.G., ASPEN, P. \& HUNTER, R.H. 1984. Xenoliths and their implications for the deep geology of the Midland Valley of Scotland and adjacent regions. Transaction of the Royal Society of Edinburgh: Earth Sciences. 75, 65-70.

UPTON, B.G.J., HINTON, R.W., ASPEN, P., FINCH, A. \& VALLEY, J.W.1999. Megacrysts and associated xenoliths: evidence for migration of geochemically enriched melts in the Upper Mantle beneath Scotland. Journal of Petrology. 40, 935956.

WALDRON, J.W.F., FLOYD, J.D., SIMONETTI, A. \& HEAMAN, L.M. 2008. Ancient Laurentian detrital zircon in the closing Iapetus Ocean, Southern Uplands Terrane, Scotland. Geology. 36, 527-530. 
WILliAMS, A. 1962. The Barr and Lower Ardmillan Series (Caradoc) of the Girvan district, south-west Ayrshire. Memoir of the Geological Society, London. 3.

WILLIAMS, D.M. \& HARPER, D.A.T. 1988. A basin model for the Silurian of the Midland Valley of Scotland and Ireland. Journal of the Geological Society, London. $145,741-748$.

\section{Figures}

Fig. 1. Simplified map showing distribution of the principal Caledonian terranes within the British Caledonides (terrane nomenclature after Bluck et al. 1992). TIC = Tyrone Igneous Complex; BC - Ballantrae Complex.

Fig. 2. Simplified geological map of the Midland Valley of Scotland showing the distribution of Silurian inliers and the Siluro-Devonian Lanark Group. Silurian inliers: A, Craighead; B, Girvan Main; C, Lesmahagow; D, Hagshaw Hills; E, Carmichael; F, Eastfield; G, Pentland Hills (North Esk). Faults: SVF, Stinchar Valley Fault; GAF, Glen App Fault; KLF, Kerse Loch Fault; BF, Bankend Fault; CCF, Carmacoup Fault; IGF, Inchgotrick Fault; CMF, Carmichael Fault; PF, Pentland Fault, CGF, Crossgatehall Fault.

Fig. 3. Generalised vertical sections through the Silurian inliers and Siluro-Devonian sequences and contemporaneous volcanic rocks of the New Cumnock, Lanark and Pentland Hills districts. The stratigraphical positions of the sandstones collected from the Hagshaw Hills, Carmichael, Eastfield and North Esk Silurian inliers of the southern Midland Valley are also shown.

Fig. 4. Photomicrographs: (a) granule sandstone, Craigskelly Formation, Girvan inlier (N5075; objective x2.5); (b) granule sandstone, Cock Rig Formation, North Esk inlier (N5071; objective x1.0); (c) microconglomerate, Parishholm Conglomerate Formation, Hagshaw Hills inlier (N5067; objective x1.0); (d) granule sandstone to pebbly sandstone, Hareshaw Conglomerate Formation, Hagshaw Hills inlier (N5068; objective x1.0); and (e) medium-grained sandstone containing aligned detrital micas 
and an elongate mudstone lithic clast, March Wood Formation, East Field inlier (N5065; objective x2.5) (all photomicrographs taken under plane polarised light).

Fig. 5. Wetherill Concordia plots for detrital zircon populations within the Silurian sandstones of the Midland Valley of Scotland: (a) sample N5075, Craigskelly Conglomerate Formation; (b) sample N5071, Cock Rig Formation; (c) sample N5067 Parisholm Conglomerate Formation; (d) sample N5068, Hareshaw Conglomerate Formation; and (e) sample N5065, March Wood Formation.

Fig. 6. Frequency distribution plots for detrital zircon populations within the Silurian sandstones of the Midland Valley of Scotland: (a) sample N5075, Craigskelly Conglomerate Formation; (b) sample N5071, Cock Rig Formation; (c) sample N5067 Parisholm Conglomerate Formation; (d) sample N5068, Hareshaw Conglomerate Formation; and (e) sample N5065, March Wood Formation.

Fig. 7. Diagram showing the possible sediment dispersal patterns within the Midland Valley terrane and Northern Belt of the Southern Uplands terrane during the Ordovician and Silurian. 


\section{Tables}

Table 1. Location details for samples of sandstone collected from the Girvan, Hagshaw Hills, Eastfield, Carmichael and North Esk/Pentland inliers of the southern Midland Valley of Scotland.

\begin{tabular}{|l|l|l|l|l|l|}
\hline $\begin{array}{l}\text { Sample } \\
\text { Number }\end{array}$ & \multicolumn{1}{|c|}{ Inlier } & \multicolumn{1}{|c|}{ Rock type } & \multicolumn{1}{|c|}{ Formation } & \multicolumn{1}{|c|}{$\begin{array}{c}\text { Agational } \\
\text { Grid } \\
\text { Reference }\end{array}$} \\
\hline N5065 & Eastfield & $\begin{array}{l}\text { medium-grained } \\
\text { sandstone }\end{array}$ & $\begin{array}{l}\text { March Wood } \\
\text { Formation }\end{array}$ & Mid-Wenlock & $\begin{array}{l}\text { NS } 9632 \\
3356\end{array}$ \\
\hline N5068 & $\begin{array}{l}\text { Hagshaw } \\
\text { Hills }\end{array}$ & granule sandstone & $\begin{array}{l}\text { Hareshaw } \\
\text { Conglomerate }\end{array}$ & Mid-Wenlock & $\begin{array}{l}\text { NS 7613 } \\
2866\end{array}$ \\
\hline N5067 & $\begin{array}{l}\text { Hagshaw } \\
\text { Hills }\end{array}$ & $\begin{array}{l}\text { granule to pebbly } \\
\text { sandstone }\end{array}$ & $\begin{array}{l}\text { Parishholm } \\
\text { Conglomerate }\end{array}$ & Lower Wenlock & $\begin{array}{l}\text { NS 7619 } \\
2812\end{array}$ \\
\hline N5071 & $\begin{array}{l}\text { North Esk } \\
\text { (Pentlands) }\end{array}$ & $\begin{array}{l}\text { very coarse- } \\
\text { grained sandstone }\end{array}$ & Cock Rig Formation & $\begin{array}{l}\text { Upper } \\
\text { Llandovery }\end{array}$ & $\begin{array}{l}\text { NS } 1482 \\
5864\end{array}$ \\
\hline N5075 & Girvan & $\begin{array}{l}\text { very coarse- } \\
\text { grained, pebbly } \\
\text { sandstone }\end{array}$ & $\begin{array}{l}\text { Craigskelly } \\
\text { Conglomerate }\end{array}$ & $\begin{array}{l}\text { Lower } \\
\text { Llandovery }\end{array}$ & $\begin{array}{l}\text { NS } 1790 \\
9615\end{array}$ \\
\hline
\end{tabular}


Table 2. Composition of sandstones from the Midland Valley selected for isotopic analysis.

\begin{tabular}{|c|c|c|c|}
\hline Sample/Formation & Major components & $\begin{array}{l}\text { Minor to accessory } \\
\text { components }\end{array}$ & Comments \\
\hline $\begin{array}{l}\text { N5065 } \\
\text { (March Wood } \\
\text { Formation) }\end{array}$ & $\begin{array}{l}\text { monocrystalline quartz and } \\
\text { variably altered igneous rock } \\
\text { fragments including granite, } \\
\text { metasandstone, biotite hornfels, } \\
\text { felsite, mica-schist, acidic } \\
\text { volcanic rock, hornblende-phyric } \\
\text { andesite or dacite, basalt, siltstone }\end{array}$ & $\begin{array}{l}\text { polycrystalline } \\
\text { quartz, muscovite, } \\
\text { biotite, opaque } \\
\text { minerals plagioclase, } \\
\text { K-feldspar, chlorite, } \\
\text { garnet, zircon }\end{array}$ & $\begin{array}{l}\text { zircon forms small } \\
\text { equant to rod- } \\
\text { shaped crystals } \\
\text { included within } \\
\text { plagioclase, quartz } \\
\text { and rarely biotite; } \\
\text { faceted zircon } \\
\text { included within } \\
\text { granite lithic clasts; } \\
\text { large rounded } \\
\text { detrital zircon in } \\
\text { matrix }\end{array}$ \\
\hline $\begin{array}{l}\text { N5068 } \\
\text { (Hareshaw } \\
\text { Conglomerate) }\end{array}$ & $\begin{array}{l}\text { mono- and polycrystalline quartz } \\
\text { and variably altered igneous rock } \\
\text { fragments including, feldspar- } \\
\text { phyric dacite, andesite, quartz- } \\
\text { schist, trachytic rock, quartz- } \\
\text { phyric rhyolite, felsite, } \\
\text { muscovite-quartz-psammite, } \\
\text { quartzite, basalt, microdiorite, } \\
\text { diorite or granodiorite, phyllite, } \\
\text { quartzofeldspathic mylonite }\end{array}$ & $\begin{array}{l}\text { polycrystalline } \\
\text { plagioclase, } \\
\text { sericitised } \\
\text { plagioclase, opaque } \\
\text { minerals, muscovite, } \\
\text { garnet, quartz- } \\
\text { chlorite vein } \\
\text { material, zircon }\end{array}$ & $\begin{array}{l}\text { zircon forms } \\
\text { rounded detrital } \\
\text { grains; equant to } \\
\text { rod-shaped crystals } \\
\text { included within } \\
\text { plagioclase and } \\
\text { quartz }\end{array}$ \\
\hline $\begin{array}{l}\text { N5067 } \\
\text { (Parishholm } \\
\text { Conglomerate) }\end{array}$ & $\begin{array}{l}\text { andesitic to dacitic igneous rock } \\
\text { fragments, monocrystalline } \\
\text { quartz, subordinate } \\
\text { polycrystalline quartz; rock } \\
\text { fragments include diorite, } \\
\text { granodiorite, microgranite, basalt, } \\
\text { plagioclase-phyric andesite, } \\
\text { quartzite, chert, feldspar-phyric } \\
\text { dacite, meta-quartz arenite, } \\
\text { felsite/chert, trachytic rock, } \\
\text { siltstone, sandstone, hornblende- } \\
\text { phyric andesite/dacite, K- } \\
\text { feldspar-rich granite (syenitic) }\end{array}$ & $\begin{array}{l}\text { micrographic } \\
\text { intergrowth, } \\
\text { microcline, chlorite, } \\
\text { muscovite, garnet, } \\
\text { epidote }\end{array}$ & $\begin{array}{l}\text { zircon forms small } \\
\text { equant to rod- } \\
\text { shaped crystals } \\
\text { included within } \\
\text { plagioclase and } \\
\text { variably strained } \\
\text { quartz; faceted } \\
\text { crystals included } \\
\text { within dioritic, } \\
\text { granodioritic, and } \\
\text { granitic lithic } \\
\text { clasts, }\end{array}$ \\
\hline $\begin{array}{l}\text { N5071 } \\
\text { (Cock Rig } \\
\text { Formation) }\end{array}$ & $\begin{array}{l}\text { rock fragments, mono- and } \\
\text { polycrystalline quartz; rock } \\
\text { fragments include quartzite, meta- } \\
\text { quartz arenite, feldspar-phyric } \\
\text { andesite or dacite, felsite/chert, } \\
\text { metasandstone, rhyolite, } \\
\text { microgranite, trachytic rock, } \\
\text { sandstone, quartz-phyric rhyolite }\end{array}$ & $\begin{array}{l}\text { plagioclase, biotite, } \\
\text { K-feldspar, } \\
\text { muscovite, apatite, } \\
\text { microcline, garnet, } \\
\text { micrographic } \\
\text { intergrowth }\end{array}$ & $\begin{array}{l}\text { zircon forms small } \\
\text { equant to rod- } \\
\text { shaped crystals } \\
\text { included in } \\
\text { plagioclase and } \\
\text { quartz }\end{array}$ \\
\hline $\begin{array}{l}\text { N5075 } \\
\text { (Craigskelly } \\
\text { Conglomerate) }\end{array}$ & $\begin{array}{l}\text { mono- and polycrystalline quartz } \\
\text { and rock fragments, including } \\
\text { basalt, quartz-phyric rhyolite, } \\
\text { siltstone, quartz-zoisite rock, } \\
\text { trachytic rock, quartzite, } \\
\text { metasandstone, phyllite, quartz- } \\
\text { feldspar-phyric rhyolite }\end{array}$ & $\begin{array}{l}\text { plagioclase, biotite, } \\
\text { opaque minerals, } \\
\text { serpentinite, chlorite, } \\
\text { muscovite, rutile, } \\
\text { apatite, tourmaline, } \\
\text { titanite, epidote, } \\
\text { garnet, zircon }\end{array}$ & $\begin{array}{l}\text { zircon forms small } \\
\text { equant to rod- } \\
\text { shaped crystals } \\
\text { included within } \\
\text { quartz and } \\
\text { muscovite; large } \\
\text { rounded detrital } \\
\text { zircons also present }\end{array}$ \\
\hline
\end{tabular}




\section{Appendix: zircon age dating analytical methods}

Laser ablation $\mathrm{U}-\mathrm{Pb}$ data were acquired using a $\mathrm{Nu}$ Instruments, $\mathrm{Nu}$ Plasma HR multicollector inductively coupled plasma mass spectrometer (MC-ICP-MS) equipped with a multi-ion-counting array. Data were collected using a single static acquisition with the configuration shown in Table A1. Instrumental parameters are detailed in Table A2.

Ablation was conducted using a $\mathrm{Nu}$ Wave Research UP193SS (193 nm), $\mathrm{Nd}$ :YAG laser ablation system and an in-house designed low volume 'zircon ablation cell', based on the design of Bleiner \& Gunther (2001). Samples were mounted in 25 mm epoxy resin discs and polished to reveal an equatorial section of the mineral grains. Ablated sample material was transported from the laser cell into the MC-ICPMS using a continuous flow of $400 \mathrm{ml} / \mathrm{min}$ of He gas.

The MC-ICP-MS was tuned at the start of each analytical session using a 300 ppt solution of $\mathrm{Tl}^{235} \mathrm{U}$ introduced via a $\mathrm{Nu}$ Instruments DSN-100 de-solvating nebuliser, using an ESI PFA-50 nebuliser tip. Ion counter (IC)-Faraday gains were determined for each of the three IC's using a weaker $50 \mathrm{ppt} \mathrm{Tl}^{2}{ }^{235} \mathrm{U}$ solution, jumping the ${ }^{205} \mathrm{Tl}$ peak through each IC, and comparing it to the equivalent Faraday signal. IC gains were of the order of 62,72 and $79 \%$ for IC0, IC1 and IC2 respectively, over the eight analytical sessions. Repeat measurement of the gains showed that these values were reproducible to within $<<0.1 \%$ (2SD) over an approximately 8 hour operating period.

Data were acquired using the $\mathrm{Nu}$ Instruments time resolved analysis (TRA) software. An instrument zero and on-peak zero were measured at the start of each run, each for a total of 60 seconds. After completion of the baselines, the laser was fired and sample data were acquired for approximately 40 seconds per ablation for a run of 10-15 (max 6) ablations. During the course of each acquisition the $\mathrm{Tl}^{235} \mathrm{U}$ solution was co-aspirated to allow for the measurement and correction of instrument induced mass bias and plasma induced elemental fractionation. ${ }^{202} \mathrm{Hg}$ was measured simultaneously, and used to correct for the isobaric interference of ${ }^{204} \mathrm{Hg}$ on the ${ }^{204} \mathrm{~Pb}$ peak, (assuming ${ }^{204} \mathrm{Hg} /{ }^{202} \mathrm{Hg}=0.229887$ ).

The laser sampling protocol employed varied, depending upon sample size. For example, where samples were large enough, a dynamic sampling approach was taken (30 x $30 \mu \mathrm{m}$ raster, using a $25 \mu \mathrm{m}$ spot and $15 \mu \mathrm{m}$ raster spacing). However, for the smaller grains found in some of the samples, a static sampling approach was taken 
using a 35-50 $\mu \mathrm{m}$ ablation spot. In all cases, samples were normalised to the relevant standard data 'like-for-like', according to spot size and fluence.

The internationally recognised 91500 zircon was used as a matrix matched standard and analysed at regular intervals throughout each session. Data were normalised according to the deviation of the average daily ${ }^{207} \mathrm{~Pb} /{ }^{206} \mathrm{~Pb}$ and ${ }^{206} \mathrm{~Pb} /{ }^{238} \mathrm{U}$ values obtained for 91500 . In the case of the latter, this is to correct for elemental fractionation in the plasma (dynamic ablation). Within-run laser-induced static elemental fractionation ablation is negligible due to ablation pit aspect ratios $<0.5$. Normalisation of the ${ }^{207} \mathrm{~Pb} /{ }^{206} \mathrm{~Pb}$ ratio of 91500 corrects for any drift, or offset, from the gain value recorded previously for the ion-counters. Uncertainties for each ratio are propagated relative to the respective reproducibility of the standard, to take into account the errors associated with the normalisation process and additionally to allow for variations in reproducibility according to count rate of the less abundant ${ }^{207} \mathrm{~Pb}$ peak.

All data were processed using an in-house spreadsheet calculation routine and are tabulated in Table A3. Data recording $<0.01 \mathrm{mV}^{207} \mathrm{~Pb}$ (i.e. below the detection limit) have been rejected and those reporting $>300 \mathrm{cps}{ }^{204} \mathrm{~Pb}$ in the sample after correction for the isobaric interference of $204 \mathrm{Hg}$ have been assessed and corrected for common- $\mathrm{Pb}$ where required. All data are plotted on Tera-Wasserberg Concordia plots (Fig. 5). Frequency distribution plots (Fig. 6) have been generated on all data $<10 \%$ discordant. All quoted data point ages are ${ }^{206} \mathrm{~Pb} /{ }^{238} \mathrm{U}$ ages unless otherwise stated.

Table A1. Configuration of the 'Zircon' collector block, used for LA-MC-ICP-MS U$\mathrm{Pb}$ analysis at NERC Isotope and Geochemistry Laboratories.

\begin{tabular}{|c|c|c|c|c|c|c|c|c|c|c|c|c|c|c|}
\hline $\begin{array}{c}\text { Ex } \\
\text { High } \\
\end{array}$ & $\begin{array}{c}\text { High } \\
6 \\
\end{array}$ & $\begin{array}{c}\text { High } \\
4 \\
\end{array}$ & $\begin{array}{c}\text { High } \\
3\end{array}$ & $\begin{array}{c}\text { High } \\
2 \\
\end{array}$ & $\begin{array}{c}\text { High } \\
1 \\
\end{array}$ & Axial & $\begin{array}{c}\text { Low } \\
1\end{array}$ & $\begin{array}{c}\text { Low } \\
2 \\
\end{array}$ & ICO & IC1 & $\begin{array}{c}\text { Low } \\
3 \\
\end{array}$ & IC2 & $\begin{array}{c}\text { Low } \\
4\end{array}$ & Low 5 \\
\hline $238 \mathrm{U}$ & $235 \mathrm{U}$ & - & - & - & - & - & - & - & $207 \mathrm{~Pb}$ & $206 \mathrm{~Pb}$ & $205 \mathrm{Tl}$ & 204Pb\&Hg & $203 \mathrm{Tl}$ & $202 \mathrm{Hg}$ \\
\hline
\end{tabular}

Table A2. Instrument and Laser operating parameters.

\begin{tabular}{|l|l|l|l|l|}
\hline ICP & $\begin{array}{l}\text { Nu Instruments, Nu } \\
\text { Plasma HR MC-ICP-MS }\end{array}$ & Model Name & $\begin{array}{l}\text { New Wave Research } \\
\text { UP193SS laser } \\
\text { ablation system }\end{array}$ \\
\hline Model Name & $1300 \mathrm{~W}$ & & $\begin{array}{l}\text { Operating } \\
\text { Wavelength }\end{array}$ & $193 \mathrm{~nm}$ \\
\hline Forward Power & $<1 \mathrm{~W}$ & Max Output & $8 \mathrm{~J} / \mathrm{cm}^{2}$ \\
\hline Reflected Power & $<$ & &
\end{tabular}




\begin{tabular}{|l|l|l|l|l|}
\hline & & & Energy & \\
\hline Cool Gas & $15 \mathrm{l} / \mathrm{min}$ & & Pulse Width & $3 \mathrm{~ns}$ \\
\hline Aux Gas & $0.8 \mathrm{l} / \mathrm{min}$ & & Repetition Rate & $1-10 \mathrm{~Hz}$ \\
\hline Nebuliser & $\begin{array}{l}\text { ESI PFA-50 }(50 \mathrm{ul} / \mathrm{min} \\
\text { uptake rate) fitted to a Nu } \\
\text { Instruments DSN-100 }\end{array}$ & & Cell Volume & $\sim 3 \mathrm{~cm}^{3}$ \\
\hline Sample Cone & $\begin{array}{l}\text { Nickel with 1.15 mm } \\
\text { orifice }\end{array}$ & & Carrier Gas & $\begin{array}{l}\text { He (flow rate } \sim 400 \\
\text { ul/min) }\end{array}$ \\
\hline Skimmer Cone & $\begin{array}{l}\text { Nickel with 0.6 mm } \\
\text { orifice }\end{array}$ & $\begin{array}{l}\text { Spot Size Range } \\
\text { used }\end{array}$ & $25-50 \mathrm{um}$ \\
\hline Collector Types & $\begin{array}{l}\text { 12 Faraday and 3 ion } \\
\text { counters (ETP discrete } \\
\text { dynode multipliers) }\end{array}$ & & & \\
\hline
\end{tabular}

Table A3. Analytical data obtained for detrital zircon populations within the Midland Valley sandstones. 


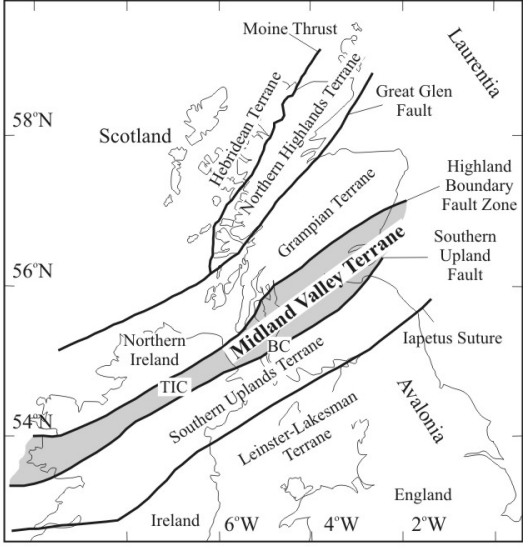

Figure 1 


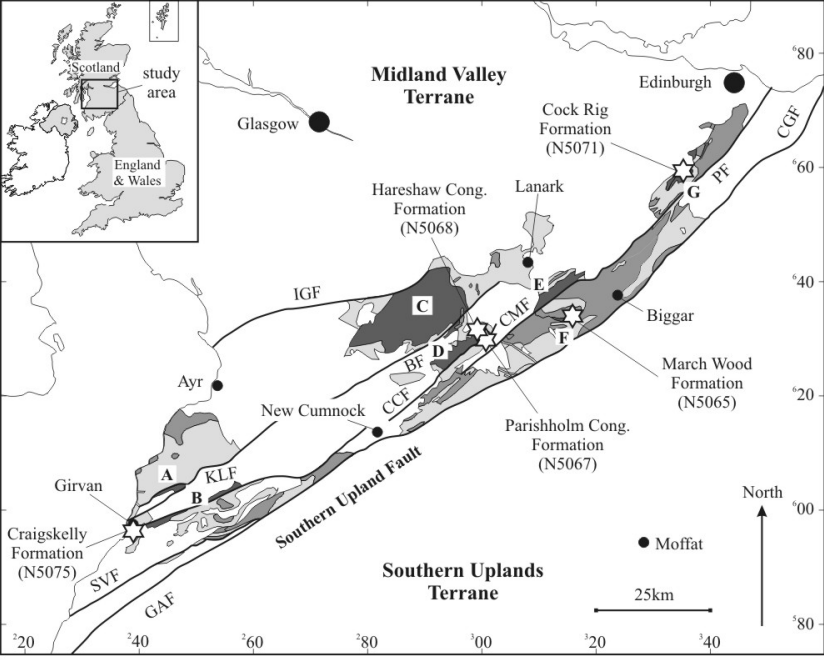

Midland Valley Silurian inliers

$\Sigma_{v}$ location of dated samples

Figure 2 


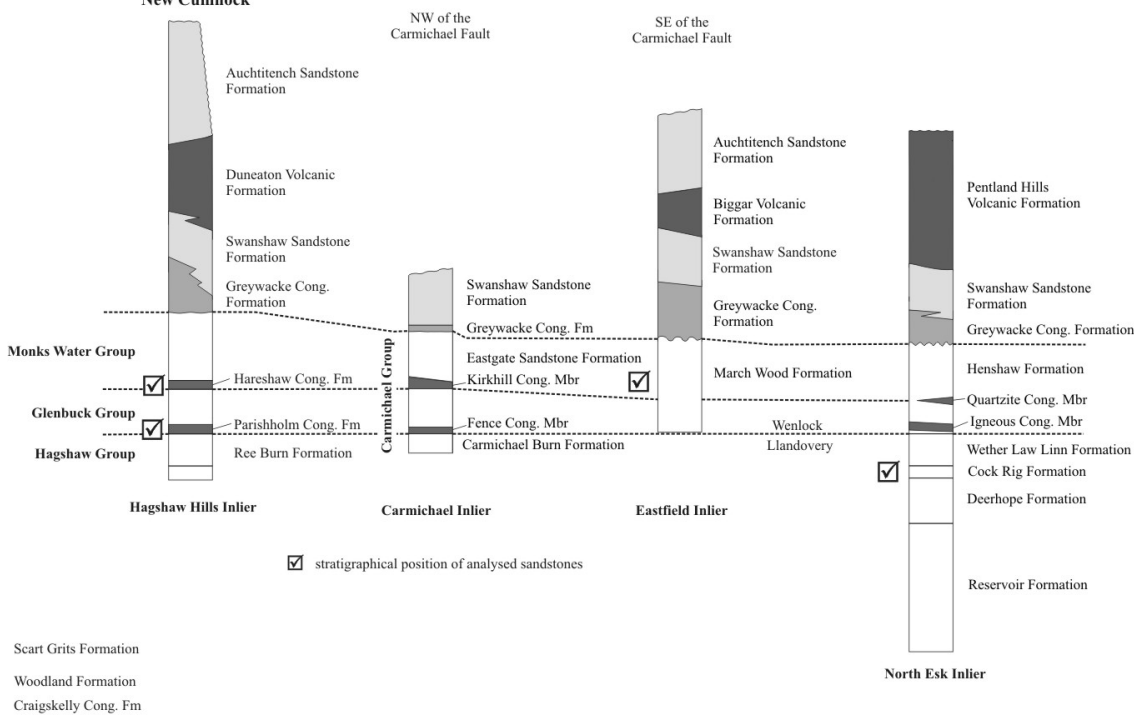



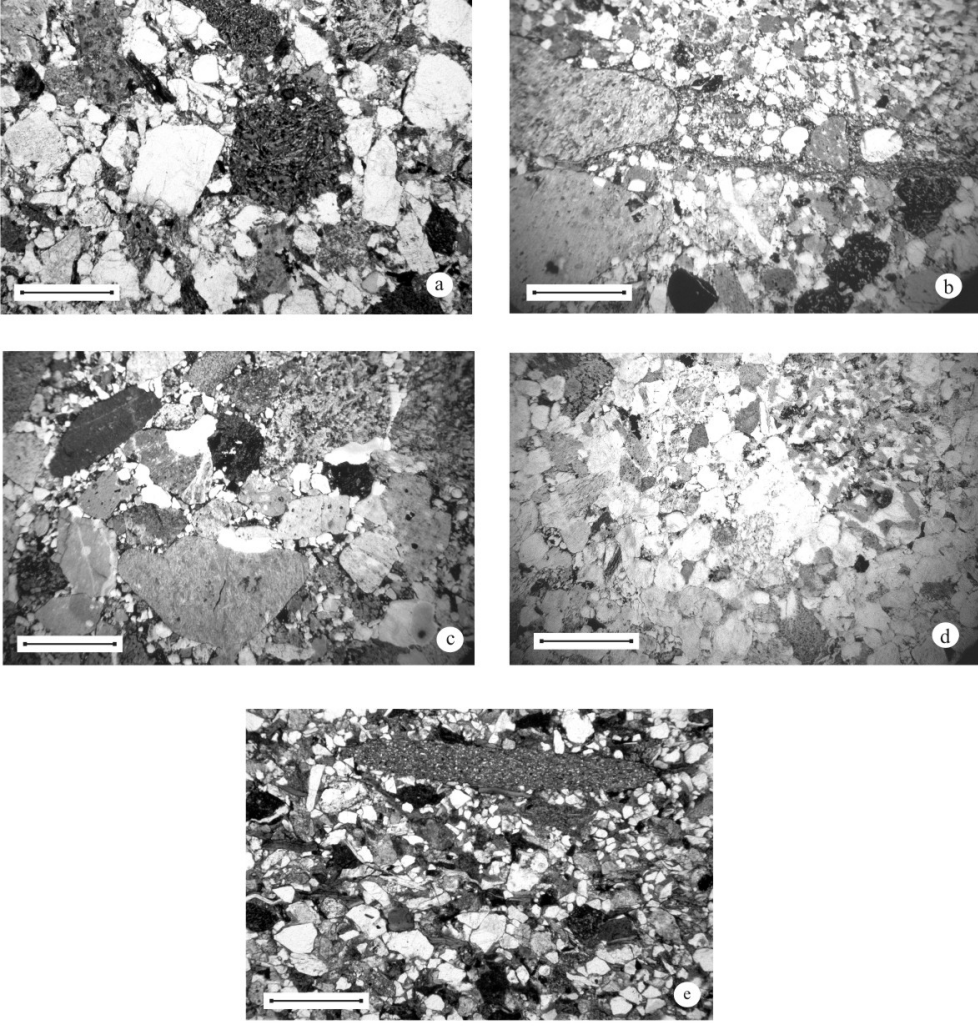

Figure 4 

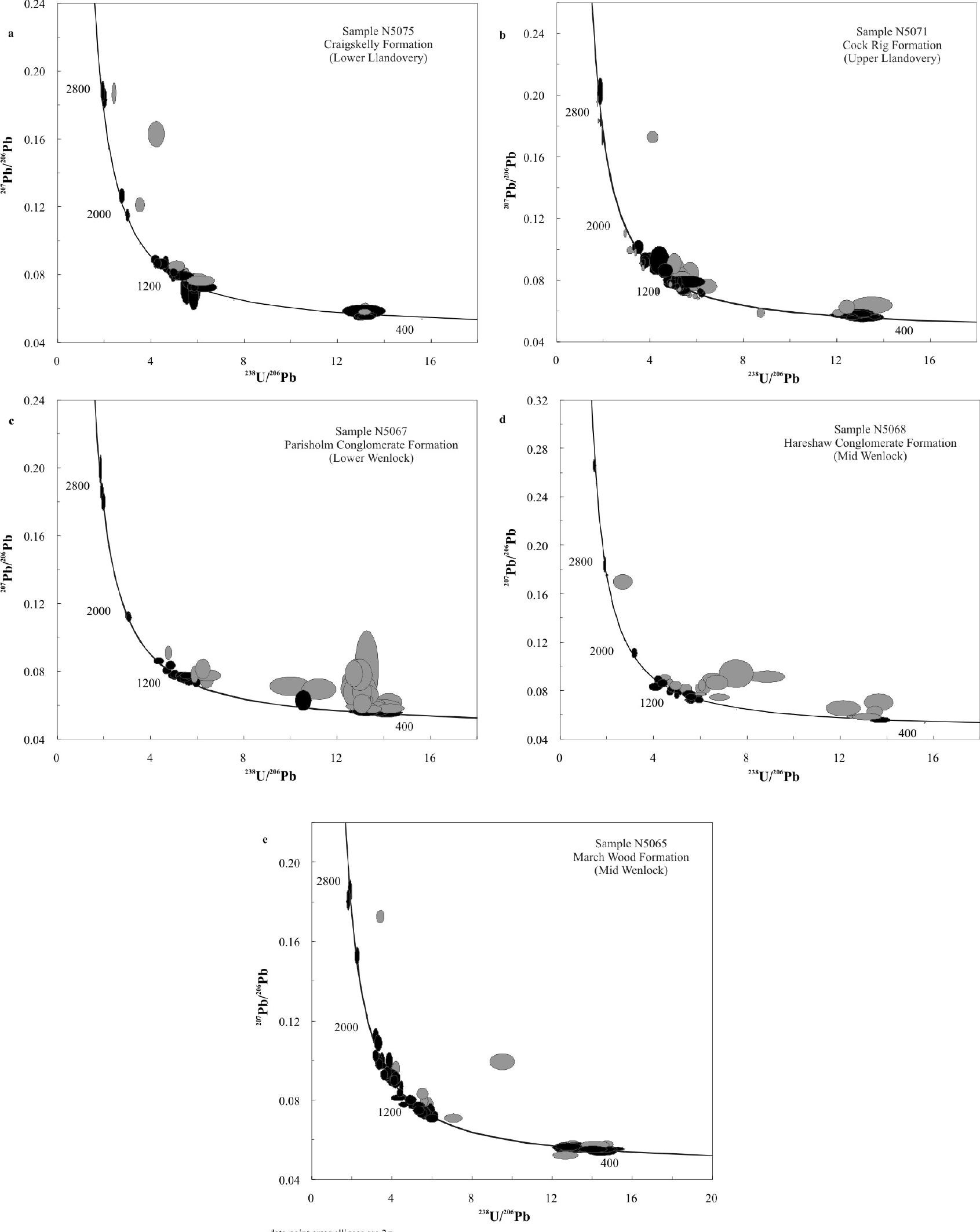

data point error ellipses are $2 \sigma$ 
